\title{
Central nervous system tumors in children under 5 years of age: a report on treatment burden, survival and long-term outcomes
}

\author{
Sarah Metzger ${ }^{1} \cdot$ Annette Weiser ${ }^{1} \cdot$ Nicolas U. Gerber ${ }^{1} \cdot$ Maria Otth $^{1,2} \cdot$ Katrin Scheinemann $^{2,3,4}$. \\ Niklaus Krayenbühl ${ }^{5}$. Michael A. Grotzer ${ }^{1}$ - Ana S. Guerreiro Stucklin ${ }^{1}$ (I)
}

Received: 28 November 2021 / Accepted: 4 February 2022 / Published online: 11 February 2022

(c) The Author(s) 2022, corrected publication 2022

\begin{abstract}
Purpose The challenges of treating central nervous system (CNS) tumors in young children are many. These include agespecific tumor characteristics, limited treatment options, and susceptibility of the developing CNS to cytotoxic therapy. The aim of this study was to analyze the long-term survival, health-related, and educational/occupational outcomes of this vulnerable patient population.

Methods Retrospective study of 128 children diagnosed with a CNS tumor under 5 years of age at a single center in Switzerland between 1990 and 2019.

Results Median age at diagnosis was 1.81 years [IQR, 0.98-3.17]. Median follow-up time of surviving patients was 8.39 years [range, 0.74-23.65]. The main tumor subtypes were pediatric low-grade glioma (36\%), pediatric high-grade glioma (11\%), ependymoma (16\%), medulloblastoma (11\%), other embryonal tumors (7\%), germ cell tumors (3\%), choroid plexus tumors (6\%), and others (9\%). The 5-year overall survival (OS) was 78.8\% (95\% CI, 71.8-86.4\%) for the whole cohort. Eightyseven percent of survivors $>5$ years had any tumor- or treatment-related sequelae with $61 \%$ neurological complications, $30 \%$ endocrine sequelae, $17 \%$ hearing impairment, and 56\% visual impairment at last follow-up. Most patients (72\%) attended regular school or worked in a skilled job at last follow-up.

Conclusion Young children diagnosed with a CNS tumor experience a range of complications after treatment, many of which are long-lasting and potentially debilitating. Our findings highlight the vulnerabilities of this population, the need for long-term support and strategies for rehabilitation, specifically tailored for young children.
\end{abstract}

Keywords Pediatrics $\cdot$ Brain tumors $\cdot$ Long-term outcome $\cdot$ Survival $\cdot$ Educational/occupational outcomes

Ana S. Guerreiro Stucklin ana.stuecklin@kispi.uzh.ch

1 Division of Oncology and Children's Research Center, University Children's Hospital of Zurich, Zurich, Switzerland

2 Division of Oncology-Hematology, Department of Pediatrics, Kantonsspital Aarau, Aarau, Switzerland

3 Department of Pediatrics, McMaster Children's Hospital and McMaster University, Hamilton, Canada

4 University of Lucerne, Lucerne, Switzerland

5 Division of Pediatric Neurosurgery, University Children's Hospital of Zurich, Zurich, Switzerland

\section{Introduction}

CNS tumors are the most common pediatric solid cancers. The average annual incidence rate is 6.18 per 100,000 in $0-4$-year-olds in the U.S. [1]. This is higher than what is reported in age groups $5-9$ years $(5.49$ per 100,000$)$ and $10-14$ years $(5.83$ per 100,000$)$ [1]. In recent years, molecular profiling studies led to major advances in the understanding and classification of pediatric CNS tumors [2-4]. Development of new therapies is ongoing and expected to increase further patient survival, mitigate long-term treatment toxicities, and improve the quality of life of survivors. Notwithstanding, CNS tumors remain the most common cause of cancer-related death in children and adolescents.

Young children ( $<5$ years of age) are particularly prone to long-term sequelae of cytotoxic therapies [5]. Radiotherapy (RT) is associated with neurocognitive and psychological 
impairment, increased risk of stroke, secondary malignancies, hearing loss, and neuroendocrine deficiencies [6]. Due to its impact on the developing CNS, RT is often entirely omitted or delayed in the management of brain tumors in young children, risking suboptimal disease control. Radiation-sparing regimens used as an alternative in this population often comprise high-dose chemotherapy with stem cell rescue as a consolidation therapy or intensified intrathecal chemotherapy. Increasing the intensity of chemotherapy has led to improved disease control, however several studies report serious events including toxic deaths, mostly due to myelosuppression, sepsis and/or organ dysfunction [7-11].

Health care professionals often face the dilemma between augmenting treatment intensity for optimal disease control and minimizing acute toxicity as well as the risk of longterm sequelae [12]. Clinical outcome and quality of life of CNS tumor survivors pose a serious concern to treating physicians as well as parents, but literature focusing on young children is scarce. Here, we describe the long-term survival, health, and academic outcomes of young children at the time of CNS tumor diagnosis and treated at our institution over the last 3 decades.

\section{Material and methods}

\section{Patient population}

In this retrospective study, young children aged 0-5 years with a newly diagnosed primary CNS tumor and treated at the University Children's Hospital of Zurich between January 1990 and December 2019 were identified. Date of diagnosis was defined as either date of histological confirmation of tissue sample or, if not available, date of diagnostic imaging.

The design of the study was approved by the Ethics Committee of the Canton of Zurich. A general research consent was implemented at our institution in 2015. The need for informed consent was waived for deceased patients, patients diagnosed prior to 2015 and lost to follow-up. Patients with documented refusal to participate in research were excluded.

\section{Clinical characteristics and long-term outcome measures}

The baseline clinical characteristics included age at diagnosis, sex, tumor characteristics (histology, location, dissemination status), hydrocephalus at diagnosis, underlying genetic predisposition and treatment details. Extent of resection was determined based on neurosurgical reports and postsurgical MRI when available; if a residual tumor was described in the neurosurgical report and/or postsurgical MRI, the tumor was considered partially resected. Progression-free survival (PFS) was calculated from date of diagnosis to disease progression leading to change in treatment or death in patients without such a progression, and overall survival (OS) from date of diagnosis to death. In the absence of progression and for patients alive at last follow-up, PFS and OS were censored at the last documented date that the patient was seen by a physician (last follow-up).

The long-term health-related outcome information was extracted from the medical charts of all patients and included neurologic status, endocrine function, hearing loss, visual acuity, secondary malignancies, and cerebral vasculopathy. Ototoxicity was graded according to Chang after review of available audiograms [13]. Neurologic status was assessed during exams at regular physician's visits and changes present in the most recent neurological examination were summarized. Neurologic deficits collected included cranial nerve deficit, motor and sensory deficits, coordination, gait, reflexes, and tonus.

At our pediatric institution, patients are followed up until 20 years of age and information on schooling and employment is regularly documented at long-term follow-up clinic visits. Academic achievement was categorized into two groups. The first group contains patients who attend regular school or work in a skilled job and the second group includes patients who attend an assisted or modified school program e.g. with smaller student numbers per class and additional assistance or who work in an unskilled or assisted job. A skilled job was defined as student with graduation after vocational training with a Federal Diploma (Fig. S3). An unskilled job includes only training on-site without graduation. Preschool-aged children were excluded from this analysis.

\section{Statistical analysis}

Descriptive analyses were used to summarize the study population. Kaplan-Meier survival curves were generated to estimate OS probability and progression-free survival probability. Log-rank test was performed for comparison between different subgroups.

To quantify the association between different treatment modalities and long-term outcomes fisher's exact test was used.

$\mathrm{R}$ version 4.0.3 and RStudio (v1.3) were used for statistical analysis. The following additional packages were used: Beeswarm, ggplot2, ggpubr, openxlsx, plotly, plotrix, plyr, survival, survminer, tableone, tidyverse, viridis.

\section{Results}

\section{Patient cohort characteristics}

We identified 164 children under 5 years of age and diagnosed with a primary CNS tumor between 1990 and 2019 
at the University Children's Hospital of Zurich, the largest pediatric oncology center in Switzerland. Thirty-six patients were excluded: 28 patients due to lack of sufficient information and 8 patients due to refusal to participate in research. Thus, 128 patients were included in the final analysis (Table S1).

The main tumor subtypes were pediatric low-grade glioma (pLGG) $(\mathrm{n}=46,35.9 \%)$, pediatric high-grade glioma (pHGG) $(\mathrm{n}=14,10.9 \%)$ including five diffuse intrinsic pontine gliomas (DIPG), ependymoma $(n=21,16.4 \%)$, medulloblastoma $(n=14,10.9 \%)$, other embryonal tumors

A
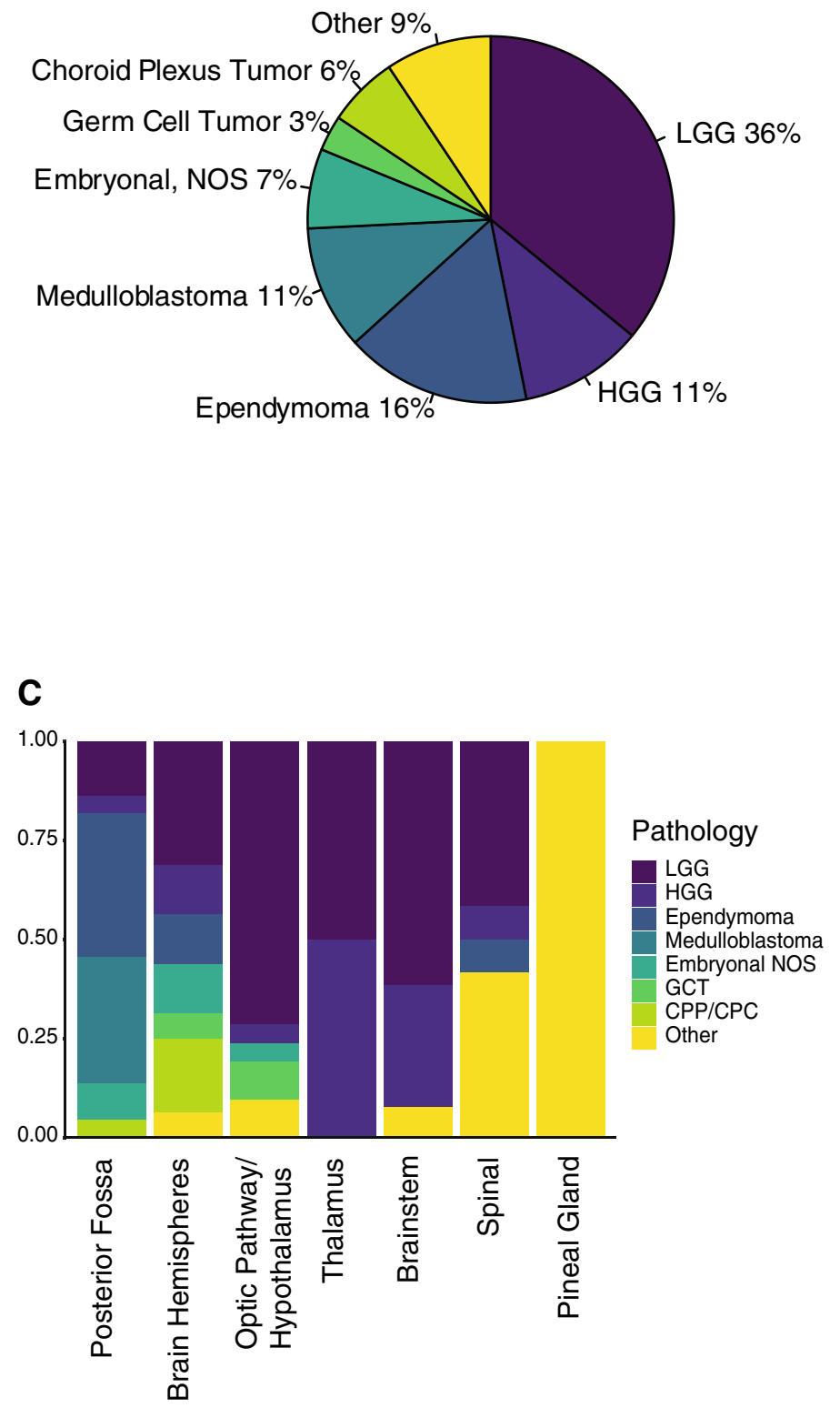

$(\mathrm{n}=9,7.0 \%)$, germ cell tumors $(\mathrm{n}=4,3.1 \%)$, choroid plexus tumors $(n=8,6.2 \%)$, and others $(n=12,9.4 \%)$ (Fig. 1A). Fourteen tumors were diagnosed based on imaging only (5 DIPG, 7 pLGG-mainly optic pathway glioma-and 2 other).

Median age at diagnosis was 1.81 years [IQR, 0.98-3.17]. Germ cell tumors $(n=4$, all mature teratomas) and choroid plexus tumors $(n=8)$ were diagnosed in children of younger age with the eldest child being 1.09 years and 1.98 years old, respectively. The other tumor subtypes showed a more balanced distribution from 0 to 5 years of age (Fig. 1B).
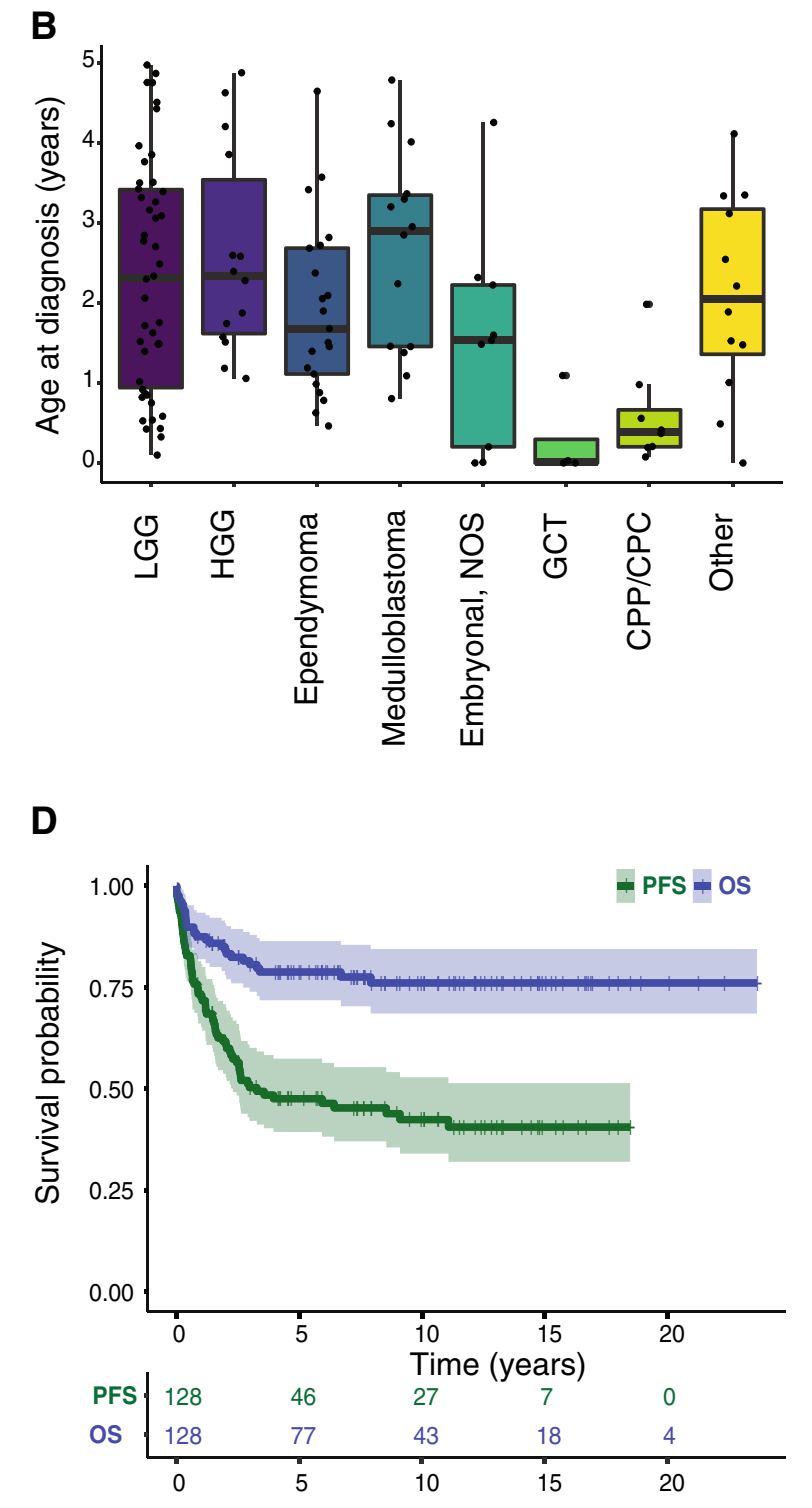

Fig. 1 Characteristics of Study Population. A Tumor subgroups in percentage of whole cohort. B Age distribution according to tumor type. C Location of tumors according to tumor type. D Progression free survival and overall survival of whole cohort with 95\%-confidence intervals and corresponding risk table. Censored cases are depicted as crosses 
The most common primary tumor site was the posterior fossa (34\%), followed by the cerebral hemispheres (26\%). Most tumors found in the optic pathway and hypothalamus/ midline region were pediatric low-grade gliomas $(n=15$, $71 \%), 3$ of those patients were diagnosed with neurofibromatosis 1 (NF1). Tumors located in the thalamus and brainstem were mostly pediatric low-grade $(n=9,56 \%)$ or highgrade gliomas $(n=6,38 \%)$ (Fig. 1C). Spinal tumors $(n=12)$ included 5 pLGG, 1 pHGG, 1 ependymoma, and 5 others (Ewing sarcoma, undifferentiated sarcoma, ganglioneuroma, juvenile xanthogranuloma, and plexiform neurofibroma).

\section{Treatment modalities}

Most patients $(n=112,87.5 \%)$ underwent surgery, in $41 \%$ gross total resection (GTR) was achieved (Table S1). Fifty percent of patients had an uneventful postoperative course, for $9 \%$ there was no detailed information available. Seven patients $(6.3 \%)$ had an ischemic event perioperatively, 5 $(4.5 \%)$ presented with hemorrhages in the perisurgical period, with one being hemodynamically relevant. Ten patients $(8.9 \%)$ developed hygroma or craniospinal fluid (CSF) leakage, 11 (9.8\%) had nerve lesions with subsequent (transient) paresis in the corresponding area and $18(16 \%)$ had other postoperative complications such as epilepsy, hemisyndromes, and endocrine deficiencies. Some patients suffered multiple complications.

Sixty-three percent of patients received chemotherapy, most of them enrolled on or treated as per tumor-specific protocols (Fig. S2; Table S2) [14, 15].

Radiotherapy was performed in $39.8 \%$ of patients $(n=51)$, either upfront $(n=27)$ or at progression $(n=24)$, two of those 24 were re-irradiated after further progression. The majority $(56.9 \%)$ underwent proton radiation (introduced in Switzerland in 1996), 37.3\% photon radiation, and $5.9 \%$ both modalities. Almost $30 \%$ underwent craniospinal radiation.

\section{Survival outcome}

Median follow-up time of surviving patients was 8.39 years [range 0.74-23.65 years]. Median progression-free survival (PFS) of the whole cohort was 3.3 years [95\% CI, 2.3-NA]. The 5- and 10-year OS probability was $78.8 \%$ resp. $76.1 \%$ for the whole cohort (Fig. 1D).

The estimated 10-year OS for patients with pLGG was 97.8\% (95\% CI, 93.7-100) (Fig. 2A) with a PFS after 5 and 10 years of $46.2 \%$ (95\% CI, 33.6-63.5) and 32.5\% (95\% CI, 19.3-54.7). Patients with pHGG had a 5- and 10-year OS probability of $35.7 \%$ (95\% CI, 17.7-72.1) (Fig. 2B), with a 5- and 10-year PFS of 28.6 (95\% CI, 12.5-65.4). Five-year OS was $80.4 \%$ (95\% CI, 64.8-99.7) and 10-year OS was 72.3\% (95\% CI, 53.7-97.5) in patients with ependymoma
(Fig. 2C) with a PFS of $45 \%$ (95\% CI, 27.5-73.7) after 5 and 10 years. Medulloblastoma patients had a 5-year OS of $55.4 \%$ (95\% CI, 32.2-95.4), and a 10-year OS of $41.5 \%$ (95\% CI, 19-91) (Fig. 2D). The 5- and 10- year PFS probability of patients with medulloblastoma was $44.4 \%$ (95\% CI, 23.2-85.2).

Most of the deceased patients died within the first 5 years after diagnosis. Of those patients who died, the majority ( 25 of $28,92.8 \%$ ) died of tumor progression/relapse. One patient initially diagnosed with medulloblastoma died after diagnosis of radiation-induced high-grade glioma. The cause of death was undocumented or unclear for two patients.

\section{Long-term health-related outcomes}

\section{Neuroendocrine sequelae}

Twenty-six patients (20.3\%) presented with endocrine deficiencies at last follow-up, where $21(81 \%)$ received hormonal replacement therapy. Most (85\%) presented with hypopituitarism. Hypopituitarism was associated with radiotherapy [odds ratio (OR) 4.51, 95\% CI 1.58-14.24] and chemotherapy (OR 3.27, 95\% CI 0.99-14.13) (Table S3). Other endocrine alterations included obesity or precocious puberty.

Fourteen patients were over 18 years of age at last followup. As far as documented none of them conceived a child. Four patients ( 4 of 8 females) had ovarian insufficiency and two required estradiol replacement. For the male patients $(n=6)$, spermiograms were not available.

\section{Visual outcomes}

Visual impairment is multifactorial and prevalent also in the general population. Focusing on the subset of patients with optic pathway glioma and tumor-associated visual impairment, all patients ( $\mathrm{n}=13 ; 2 / 13$ patients with NF1) with optic pathway glioma showed some degree of visual impairment at last follow-up and four patients were blind in at least one eye.

\section{Hearing outcome}

Sixteen patients $(12.5 \%)$ had hearing impairment at last follow-up ( $\geqq$ Chang Grade 2b) (Table 1). We found an association between hearing impairment and platinum containing chemotherapy (OR 6.898, 95\% CI 1.457-65.911) and radiotherapy (OR 3.915, 95\% CI 1.155-15.435) (Table S3).

\section{Secondary malignancies}

Three patients were diagnosed with a secondary malignancy during follow-up (Table 2). All of them had been irradiated by either proton or photon radiation, received 

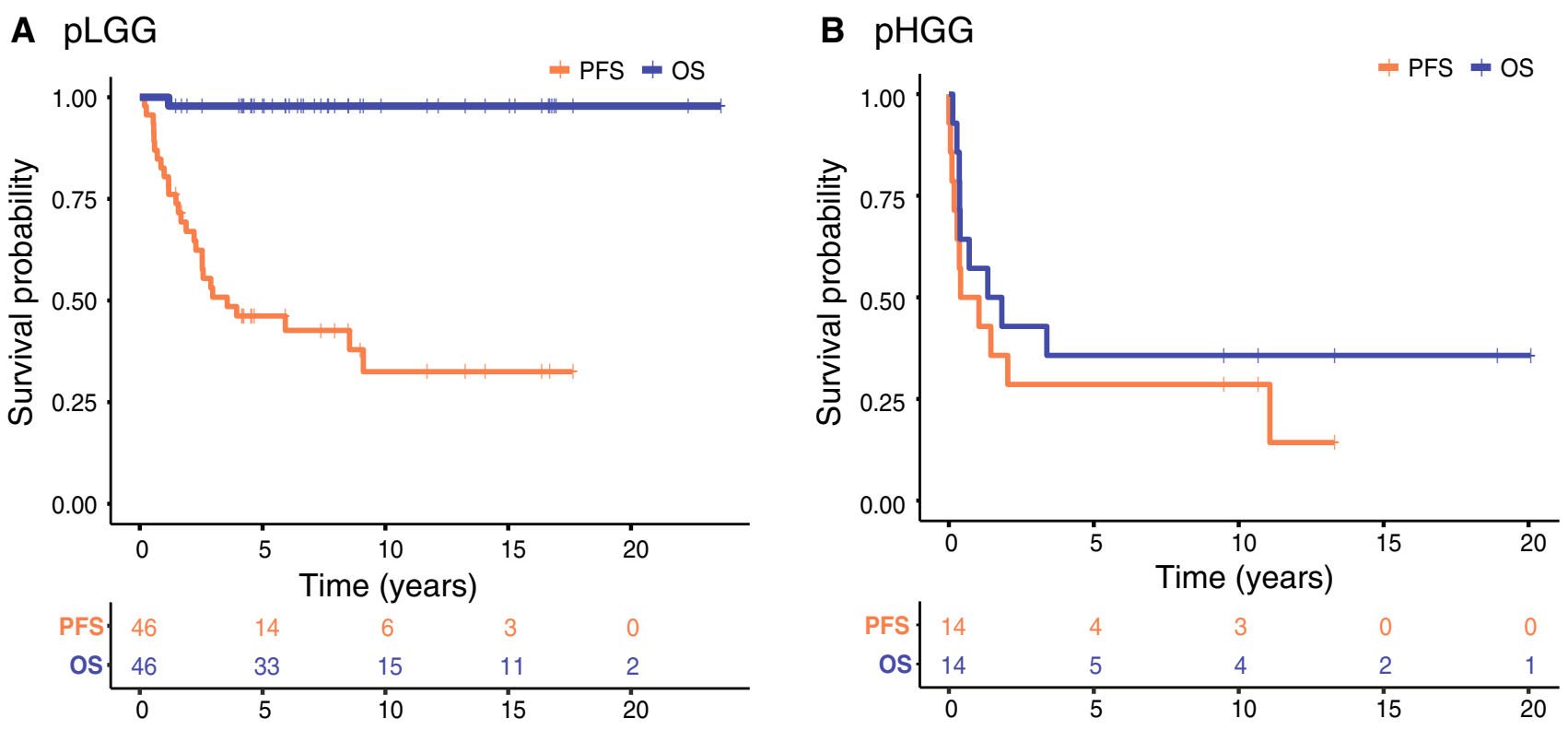

\section{Ependymoma}
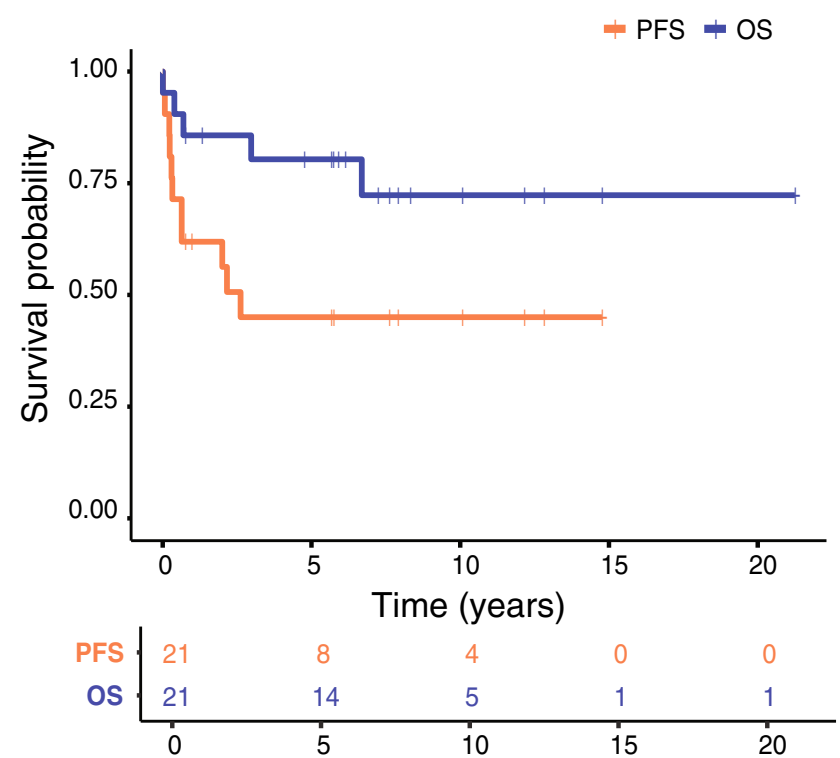

D Medulloblastoma

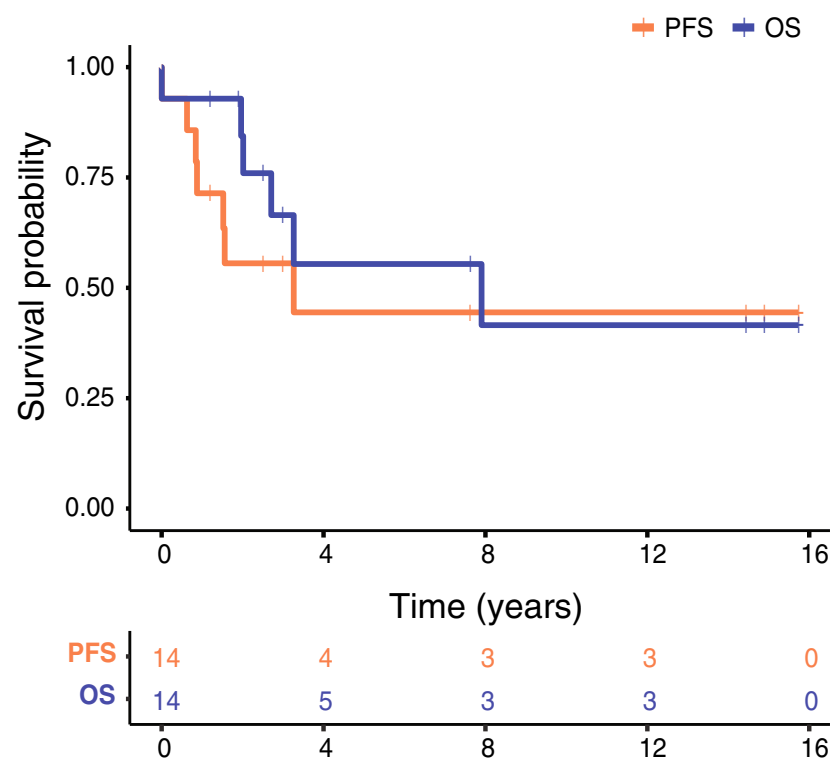

Fig. 2 Kaplan-Meier Curves A-D depicting progression free survival and overall survival of the four main tumor subgroups with corresponding risk-tables. Censored cases are depicted as crosses

chemotherapy, and underwent surgery. None of them had a known underlying genetic predisposition, including NF1. Importantly, the patient with ATRT and later MPNST had no evidence of germline alterations in SMARCB1, SMARCA4, NF1 or TP53. One patient succumbed to his secondary malignancy.

\section{Cerebrovascular disease}

Two out of 51 irradiated patients (3.9\%) presented with a moyamoya vasculopathy during follow-up. Both had been diagnosed with posterior fossa ependymoma and had received focal proton radiation at below 4 years of 
Table 1 Health-related outcomes for each tumor subgroup

\begin{tabular}{|c|c|c|c|c|c|c|c|c|c|}
\hline & LGG & HGG & $\begin{array}{l}\text { Epend- } \\
\text { ymoma }\end{array}$ & $\begin{array}{l}\text { Medullo- } \\
\text { blastoma }\end{array}$ & $\begin{array}{l}\text { Embryonal } \\
\text { tumor }\end{array}$ & $\begin{array}{l}\text { Germ cell } \\
\text { tumor }\end{array}$ & $\begin{array}{l}\text { Choroid } \\
\text { plexus tumor }\end{array}$ & Other & Total n (\%) \\
\hline $\mathrm{n}$ & 46 & 14 & 21 & 14 & 9 & 4 & 8 & 12 & $128(100)$ \\
\hline $\begin{array}{l}\text { Age at diag- } \\
\text { nosis years } \\
\text { (median } \\
{[\mathrm{IQR}] \text { ) }}\end{array}$ & $\begin{array}{l}2.32[0.94 \\
3.41]\end{array}$ & $\begin{array}{c}2.34[1.62, \\
3.54]\end{array}$ & $\begin{array}{l}1.68[1.11, \\
2.68]\end{array}$ & $\begin{array}{c}2.90[1.46, \\
3.35]\end{array}$ & $\begin{array}{l}1.53[0.20, \\
2.22]\end{array}$ & $\begin{array}{l}0.02[0.00 \\
0.30]\end{array}$ & $\begin{array}{c}0.39[0.20, \\
0.66]\end{array}$ & $\begin{array}{l}2.05[1.36 \\
3.17]\end{array}$ & \\
\hline $\begin{array}{l}\text { Any } \\
\text { abnormal } \\
\text { neurologi- } \\
\text { cal finding } \\
(\%)\end{array}$ & $26(56.5)$ & $10(71.4)$ & $12(57.1)$ & $10(71.4)$ & $6(66.7)$ & $2(50.0)$ & $6(75.0)$ & $7(58.3)$ & 79 (61.7) \\
\hline Seizures $(\%)$ & $10(21.7)$ & $3(21.4)$ & $1(4.8)$ & $4(28.6)$ & $5(55.6)$ & $1(25.0)$ & $2(25.0)$ & $2(16.7)$ & 28 (21.9) \\
\hline $\begin{array}{l}\text { Neuroen- } \\
\text { docrine } \\
\text { sequelae } \\
(\%)\end{array}$ & $10(21.7)$ & $1(7.1)$ & $6(28.6)$ & $4(28.6)$ & $2(22.2)$ & $1(25.0)$ & $1(12.5)$ & $3(25.0)$ & $28(21.9)^{*}$ \\
\hline \multicolumn{10}{|c|}{ Hearing outcome (\%) } \\
\hline $\begin{array}{l}\text { Chang } \\
\text { Grade } 0\end{array}$ & $39(84.8)$ & $12(85.7)$ & $13(61.9)$ & $10(71.4)$ & $8(88.9)$ & $3(75.0)$ & $7(87.5)$ & $12(100.0)$ & $104(81.2)$ \\
\hline $\begin{array}{l}\text { Chang } \\
\text { Grade 1b }\end{array}$ & $1(2.2)$ & $0(0.0)$ & $2(9.5)$ & $2(14.3)$ & $0(0.0)$ & $0(0.0)$ & $0(0.0)$ & $0(0.0)$ & $5(3.9)$ \\
\hline $\begin{array}{l}\text { Chang } \\
\text { Grade 2a }\end{array}$ & $2(4.4)$ & $0(0.0)$ & $0(0.0)$ & $0(0.0)$ & $0(0.0)$ & $0(0.0)$ & $0(0.0)$ & $0(0.0)$ & $2(1.5)$ \\
\hline $\begin{array}{l}\text { Chang } \\
\text { Grade 2b }\end{array}$ & $1(2.2)$ & $0(0.0)$ & $0(0.0)$ & $0(0.0)$ & $0(0.0)$ & $1(25.0)$ & $1(12.5)$ & $0(0.0)$ & $3(2.3)$ \\
\hline $\begin{array}{l}\text { Chang } \\
\text { Grade } 3\end{array}$ & $1(2.2)$ & $1(7.1)$ & $1(4.8)$ & $2(14.3)$ & $0(0.0)$ & $0(0.0)$ & $0(0.0)$ & $0(0.0)$ & $5(3.9)$ \\
\hline $\begin{array}{l}\text { Chang } \\
\text { Grade } 4\end{array}$ & $1(2.2)$ & $1(7.1)$ & $5(23.8)$ & $0(0.0)$ & $1(11.1)$ & $0(0.0)$ & $0(0.0)$ & $0(0.0)$ & $8(6.2)$ \\
\hline
\end{tabular}

*Including 2 patients with transient endocrine alterations

Table 2 Characteristics of patients with diagnosis of a secondary malignancy

\begin{tabular}{llllllllll}
\hline $\begin{array}{l}\text { Age at diagnosis } \\
\text { of first tumor } \\
\text { (years) }\end{array}$ & Sex & $\begin{array}{c}\text { Pathology pri- } \\
\text { mary tumor }\end{array}$ & Deceased & OS (years) & Surgery & Chemo & Radiation & $\begin{array}{c}\text { Time from first } \\
\text { diagnosis to } \\
\text { second (years) }\end{array}$ & $\begin{array}{c}\text { Type of secondary } \\
\text { malignancy }\end{array}$ \\
\hline 2.3 & Male & $\begin{array}{c}\text { Fibrillary astro- } \\
\text { cytoma }\end{array}$ & No & 16.9 & Yes, GTR & Yes & Yes, Photon & 9.2 & T-ALL \\
1.5 & Female & ATRT & No & 12.2 & Yes, STR & Yes & Yes, Proton & 10.5 & $\begin{array}{c}\text { Malignant periph- } \\
\text { eral nerve sheath } \\
\text { tumour (outside } \\
\text { of radiation field) }\end{array}$ \\
3.4 & Male & $\begin{array}{c}\text { Classic medul- } \\
\text { loblastoma }\end{array}$ & Yes & 3.3 & Yes, GTR & Yes & Yes, Photon & 3.2 & $\begin{array}{c}\text { High grade diffuse } \\
\text { brainstem glioma }\end{array}$ \\
\hline
\end{tabular}

age, with a dose to the tumor bed of 54 Gy and $59.4 \mathrm{~Gy}$, respectively.

Nine patients (7\%) experienced a stroke during follow-up time, in four patients after surgical resection of the tumor and in 2 patients stroke was deemed related to radiation-induced cerebrovascular disease ( 2.5 years and 13 years post completion of radiation).
In summary, among survivors followed for more than 5 years $(n=77), 87 \%$ present with any tumor- or treatmentrelated sequelae, $61 \%$ had any neurological deficit, $30 \%$ presented with endocrine sequelae and $81 \%$ of them with need for hormone replacement, $17 \%$ with hearing impairment, and $56 \%$ with visual impairment at last follow-up. 


\section{Education and occupational outcomes}

Thirty-seven patients had not yet reached school age at time of last follow-up. Information on schooling was not available for 6 patients. Of the remaining 85 patients, $71.8 \%$ were able to attend regular school and/or work in a skilled job, whereas $28.2 \%$ were schooled in a modified program or working in an unskilled or assisted job (Fig. 3). Of the patients over 18 years of age at last follow-up $(n=14)$, one patient attended university. Fifteen of 68 (22\%) patients 1 year or older at diagnosis were schooled in a special school environment or working in an unskilled job, compared to 9 out of $17(53 \%)$ patients under 1 year of age at diagnosis. Despite limited patient numbers, this trend suggests lower academic achievement in children diagnosed in the first year of life.

\section{Discussion}

Among survivors of childhood cancer, the cumulative burden of chronic health conditions is highest in patients diagnosed with CNS malignancies [16]. Providing treatments which are both efficient and of acceptable toxicity is thus a great challenge in pediatric neuro-oncology, especially when treating young children. A report from the Childhood Cancer Survivor Study (CCSS) suggested that treatment transformation over the past decades has already decreased the overall treatment burden [17]. Nevertheless, the long-term impact of therapy in the immature CNS and in the developing child remains a major concern. In addition, CNS tumors in young children often display distinct clinical and biological features when compared to those in older children and adolescents [18-21]. In this study we report the survival, health-related and educational outcomes of young children with CNS tumors treated at a tertiary pediatric oncology center over a period of three decades. Importantly, our study provides long follow-up and comprehensive clinical outcome data on a large cohort of sequentially diagnosed, unselected patients in this age group. We found that mortality was largely due to tumor progression/relapse and predominantly within the first 5 years after diagnosis. The high prevalence of tumorand treatment-related sequelae (87\%) highlights the need for close monitoring and long-term, multidisciplinary support strategies.

With a 5-year OS of $78.8 \%$, the survival outcome of our cohort is comparable to previous studies, albeit differences regarding patient characteristics and therapy between studies [1,22-24]. One study including 35 children under 1 year of age at diagnosis reported a considerably lower 5 -year OS of $57 \%$ [25]. The OS of pLGG in our cohort seems to be better than reported in previous studies [20,21], which were multi-institutional and thus more heterogenous in treatment approach. PFS was defined in our study as time from diagnosis to a progression leading to change in treatment. This may overestimate PFS compared to other studies with other definitions and should be considered when interpreting our results, especially for patients with pLGG.

Other studies reported a higher mortality rate in children diagnosed under 1 year of age when compared to older children $[20,26,27]$. Despite a trend in literature towards worse outcome in children diagnosed in the first year of life, we could not confirm this finding in our cohort, noting however a trend towards worse OS in children diagnosed in the first 6 months of life (Fig. S1) [28]. This may be explained by differences in patient characteristics (age at diagnosis limited to 5 years or younger in this study) and tumor distribution (e.g. lower numbers of patients with ATRT in our cohort).

Survival rates of children diagnosed with a CNS tumor seem to have increased over the last years [23, 24], while the prognosis for high grade subtypes remains poor. Similarly, despite encouraging survival rates of the whole cohort, patients with pHGG and medulloblastoma had an
Fig. 3 Educational/occupational outcomes by age at last follow-up

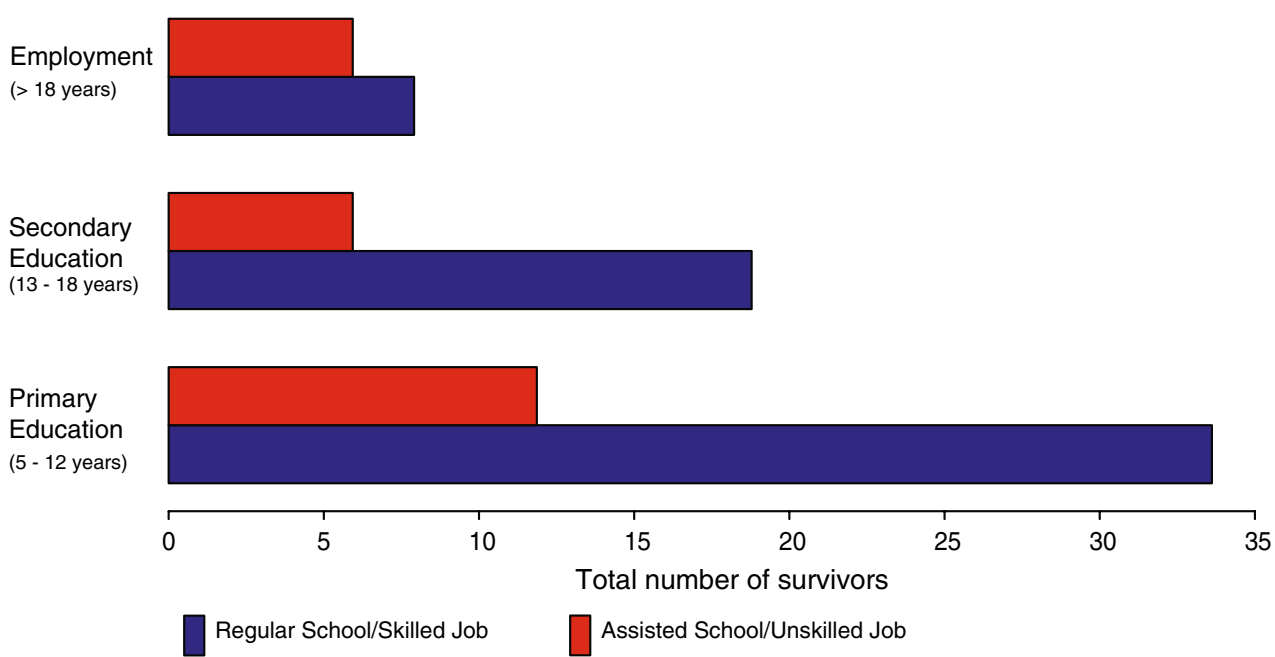


unfavorable outcome, with a 5-year OS of $35.7 \%$ and 55.4\%, respectively.

A study summarizing the outcomes of a cohort of 20 survivors, previously diagnosed with a brain tumor in the first year of life, reported $70 \%$ with neurological dysfunction, $25 \%$ with endocrine dysfunction, $15 \%$ with hearing impairment, and $45 \%$ with visual impairment [25]. These numbers are comparable to our findings, despite differences in age of inclusion. A report from the CCSS showed that patients diagnosed with a CNS malignancy had a significantly higher risk of developing a chronic health condition 5 years after diagnosis when compared to their siblings, including endocrine, neurologic, or sensory deficits [29]. Hearing impairment was associated with radiation therapy and platinum chemotherapy, both known risk factors for sensorineural hearing loss [30, 31]. A previous study from the CCSS reported hearing impairment in $12 \%$ of childhood CNS tumors survivors [30]. A study conducted at St. Jude Children's Hospital compared survivors of CNS tumors to survivors of non-CNS tumors exposed to high-risk ototoxic cancer therapy and reported a prevalence of $36 \%$ of severe hearing loss in CNS tumor survivors. There was no association between age at diagnosis and hearing loss [32].

Hypopituitarism was associated with radiotherapy, as previously described [33-35]. A recent study identified younger age, tumor location, and radiotherapy as relevant risk factors for developing hypothalamic-pituitary disease [36]. Due to lack of sufficient information, an analysis on radiation dose-dependent outcomes was not possible in our cohort. A report from the CCSS could not find a dose-dependent risk elevation in radiotherapy for endocrine deficits [37]. The important issue of fertility could not be addressed in a uniform manner in our cohort and should be addressed in future studies.

We found that most (71.8\%) of our school-aged patients or older at the time of analysis attended regular school or were employed in a skilled job. This is higher than what a previous study reported including children diagnosed with a CNS tumor in the first year of life [25]. A recent study with children aged 4 years or younger at diagnosis and treated with proton radiotherapy described a rate of $90 \%$ of children functioning in regular schools, $46 \%$ of them followed a specialized educational plan, whereas $23 \%$ and $36 \%$ had a classroom aid or outside tutor, respectively [38]. Interestingly, recent analyses of childhood cancer survivors showed that especially CNS malignancy, younger age at diagnosis, and radiotherapy increased the risk of unemployment and lower educational attainment [39-41]. Another analysis showed that childhood survivors of CNS tumors were less likely to complete high school than their siblings but could lower that risk by using special education support [42]. These findings further highlight the need to develop toxicity-sparing treatments and provide long-term support for these patients.
The size and heterogeneity of our study population, as well as limitations associated with the retrospective nature of the study, need to be considered when interpreting our findings. Assessment of long-term outcome has not followed a standard procedure in terms of frequency and tools used, limiting interpatient comparisons. The classification of CNS tumors has undergone several important revisions over the decades covered in this study. The main tumor entities have been reclassified and subdivided into new subgroups, reflecting the heterogeneity in tumor biology, especially in pediatric brain tumors in young children [3, 43]. Though molecular profiling was beyond the scope of this study, future studies dissecting correlation between tumor biology and healthrelated outcome will be critical to understand the impact of tumor biology on long term functional outcomes. A further limitation of our study is lack of comparison cohort of older pediatric and adolescent patients diagnosed with CNS tumors. Nevertheless, our findings provide a comprehensive overview of an unselected large cohort of patients, diagnosed and followed by a multidisciplinary team in a tertiary center over a period spanning 3 decades.

\section{Conclusions}

Young children are at a high risk for long-term morbidity after diagnosis of a CNS tumor. Encouragingly, though a vast proportion of survivors experience health-related sequelae, most were integrated in regular schools. Our study highlights the importance of long-term support strategies, tailored to young children. These include early screening for visual and hearing impairment, as well as endocrinopathy and neuropsychology assessments, to offer appropriate support. Advances in treatment modalities, including targeted anti-tumor therapies and improvement in high-precision radiation techniques, will hopefully lead to a further reduction in treatment burden and better long-term outcomes in these children.

Supplementary Information The online version contains supplementary material available at https://doi.org/10.1007/s11060-022-03963-3.

Acknowledgements We would like to thank Niels Hagenbuch, MD MSc Statistics ETH, for the statistical support.

Author contributions Study conception and design by SM, MG and AGS. Data collection by SM and AW. All authors were involved in data curation, analysis, and interpretation of the results. First manuscript draft written by SM and AGS. All authors reviewed, edited, and approved the final manuscript.

Funding Open access funding provided by University of Zurich. AGS was supported by Grants from the Fondation FORCE, Fonds 
zur Förderung des akademischen Nachwuchses der Universität Zürich, Promedica Stiftung.

Data availability The datasets generated during and/or analysed during the current study are available from the corresponding author on reasonable request.

\section{Declarations}

Conflict of interest The authors have no relevant financial or non-financial interests to disclose.

Ethical approval The design of the study was approved by the Ethics Committee of the Canton of Zurich, Switzerland (Nr. 2020-00801).

Consent to participate A general research consent was implemented at our institution in 2015. The need for informed consent was waived for deceased patients, patients diagnosed prior to 2015 and lost to followup. Patients who refused general consent were excluded from the study.

Open Access This article is licensed under a Creative Commons Attribution 4.0 International License, which permits use, sharing, adaptation, distribution and reproduction in any medium or format, as long as you give appropriate credit to the original author(s) and the source, provide a link to the Creative Commons licence, and indicate if changes were made. The images or other third party material in this article are included in the article's Creative Commons licence, unless indicated otherwise in a credit line to the material. If material is not included in the article's Creative Commons licence and your intended use is not permitted by statutory regulation or exceeds the permitted use, you will need to obtain permission directly from the copyright holder. To view a copy of this licence, visit http://creativecommons.org/licenses/by/4.0/.

\section{References}

1. Ostrom QT, Patil N, Cioffi G, Waite K, Kruchko C, BarnholtzSloan JS (2020) CBTRUS statistical report: primary brain and other central nervous system tumors diagnosed in the United States in 2013-2017. Neuro Oncol 22:1-96. https://doi.org/10. 1093/neuonc/noaa200

2. Capper D, Jones DTW, Sill M, Hovestadt V, Schrimpf D, Sturm D, Koelsche C, Sahm F, Chavez L, Reuss DE, Kratz A, Wefers AK, Huang K, Pajtler KW, Schweizer L, Stichel D, Olar A, Engel NW, Lindenberg K, Harter PN, Braczynski AK, Plate KH, Dohmen H, Garvalov BK, Coras R, Hölsken A, Hewer E, Bewerunge-Hudler M, Schick M, Fischer R, Beschorner R, Schittenhelm J, Staszewski O, Wani K, Varlet P, Pages M, Temming P, Lohmann D, Selt F, Witt H, Milde T, Witt O, Aronica E, Giangaspero F, Rushing E, Scheurlen W, Geisenberger C, Rodriguez FJ, Becker A, Preusser M, Haberler C, Bjerkvig R, Cryan J, Farrell M, Deckert M, Hench J, Frank S, Serrano J, Kannan K, Tsirigos A, Brück W, Hofer S, Brehmer S, Seiz-Rosenhagen M, Hänggi D, Hans V, Rozsnoki S, Hansford JR, Kohlhof P, Kristensen BW, Lechner M, Lopes B, Mawrin C, Ketter R, Kulozik A, Khatib Z, Heppner F, Koch A, Jouvet A, Keohane C, Mühleisen H, Mueller W, Pohl U, Prinz M, Benner A, Zapatka M, Gottardo NG, Driever PH, Kramm CM, Müller HL, Rutkowski S, von Hoff K, Frühwald MC, Gnekow A, Fleischhack G, Tippelt S, Calaminus G, Monoranu CM, Perry A, Jones C, Jacques TS, Radlwimmer B, Gessi M, Pietsch T, Schramm J, Schackert G, Westphal M, Reifenberger G, Wesseling P, Weller M, Collins VP, Blümcke I, Bendszus M, Debus J, Huang
A, Jabado N, Northcott PA, Paulus W, Gajjar A, Robinson GW, Taylor MD, Jaunmuktane Z, Ryzhova M, Platten M, Unterberg A, Wick W, Karajannis MA, Mittelbronn M, Acker T, Hartmann C, Aldape K, Schüller U, Buslei R, Lichter P, Kool M, Herold-Mende C, Ellison DW, Hasselblatt M, Snuderl M, Brandner S, Korshunov A, von Deimling A, Pfister SM (2018) DNA methylationbased classification of central nervous system tumours. Nature 555:469-474. https://doi.org/10.1038/nature26000

3. Guerreiro Stucklin AS, Ramaswamy V, Daniels C, Taylor MD (2018) Review of molecular classification and treatment implications of pediatric brain tumors. Curr Opin Pediatr 30:3-9. https:// doi.org/10.1097/MOP.0000000000000562

4. Fangusaro J, Bandopadhayay P (2021) Advances in the classification and treatment of pediatric brain tumors. Curr Opin Pediatr 33:26-32. https://doi.org/10.1097/MOP.0000000000000975

5. Johnson KJ, Cullen J, Barnholtz-Sloan JS, Ostrom QT, Langer CE, Turner MC, McKean-Cowdin R, Fisher JL, Lupo PJ, Partap S, Schwartzbaum JA, Scheurer ME (2014) Childhood brain tumor epidemiology: a brain tumor epidemiology consortium review. Cancer Epidemiol Biomark Prev 23:2716-2736. https://doi.org/ 10.1158/1055-9965.EPI-14-0207

6. Williams NL, Rotondo RL, Bradley JA, Pincus DW, Fort JA, Wynn T, Morris CG, Mendenhall NP, Indelicato DJ (2018) Late effects after radiotherapy for childhood low-grade glioma. Am J Clin Oncol 41:307-312. https://doi.org/10.1097/COC.00000 00000000267

7. Lafay-Cousin L, Smith A, Chi SN, Wells E, Madden J, Margol A, Ramaswamy V, Finlay J, Taylor MD, Dhall G, Strother D, Kieran MW, Foreman NK, Packer RJ, Bouffet E (2016) Clinical, pathological, and molecular characterization of infant medulloblastomas treated with sequential high-dose chemotherapy. Pediatr Blood Cancer 63:1527-1534. https://doi.org/10.1002/pbc.26042

8. Cohen BH, Geyer JR, Miller DC, Curran JG, Zhou T, Holmes E, Ingles SA, Dunkel IJ, Hilden J, Packer RJ, Pollack IF, Gajjar A, Finlay JL, Group CsO (2015) Pilot study of intensive chemotherapy with peripheral hematopoietic cell support for children less than 3 years of age with malignant brain tumors, the CCG-99703 phase I/II study. A report from the Children's Oncology Group. Pediatr Neurol 53:31-46. https://doi.org/10.1016/j.pediatrneurol. 2015.03.019

9. Espinoza JC, Haley K, Patel N, Dhall G, Gardner S, Allen J, Torkildson J, Cornelius A, Rassekh R, Bedros A, Etzl M, Garvin J, Pradhan K, Corbett R, Sullivan M, McGowage G, Stein D, Jasty R, Sands SA, Ji L, Sposto R, Finlay JL (2016) Outcome of young children with high-grade glioma treated with irradiation-avoiding intensive chemotherapy regimens: final report of the Head Start II and III trials. Pediatr Blood Cancer 63:1806-1813. https://doi. org/10.1002/pbc.26118

10. Dhall G, Grodman H, Ji L, Sands S, Gardner S, Dunkel IJ, McCowage GB, Diez B, Allen JC, Gopalan A, Cornelius AS, Termuhlen A, Abromowitch M, Sposto R, Finlay JL (2008) Outcome of children less than three years old at diagnosis with non-metastatic medulloblastoma treated with chemotherapy on the "Head Start" I and II protocols. Pediatr Blood Cancer 50:1169-1175. https://doi.org/10.1002/pbc.21525

11. Mason WP, Grovas A, Halpern S, Dunkel IJ, Garvin J, Heller G, Rosenblum M, Gardner S, Lyden D, Sands S, Puccetti D, Lindsley K, Merchant TE, O’Malley B, Bayer L, Petriccione MM, Allen J, Finlay JL (1998) Intensive chemotherapy and bone marrow rescue for young children with newly diagnosed malignant brain tumors. J Clin Oncol 16:210-221. https://doi.org/10.1200/JCO.1998.16.1. 210

12. Pui CH, Gajjar AJ, Kane JR, Qaddoumi IA, Pappo AS (2011) Challenging issues in pediatric oncology. Nat Rev Clin Oncol 8:540-549. https://doi.org/10.1038/nrclinonc.2011.95 
13. Chang KW, Chinosornvatana N (2010) Practical grading system for evaluating cisplatin ototoxicity in children. J Clin Oncol 28:1788-1795. https://doi.org/10.1200/JCO.2009.24.4228

14. Gnekow AK, Walker DA, Kandels D, Picton S, Perilongo G, Grill J, Stokland T, Sandstrom PE, Warmuth-Metz M, Pietsch T, Giangaspero F, Schmidt R, Faldum A, Kilmartin D, De Paoli A, De Salvo GL, Centers otLGGCatp (2017) A European randomised controlled trial of the addition of etoposide to standard vincristine and carboplatin induction as part of an 18-month treatment programme for childhood ( $\leq 16$ years) low grade glioma - a final report. Eur J Cancer 81:206-225. https://doi.org/10.1016/j.ejca. 2017.04.019

15. Mynarek M, von Hoff K, Pietsch T, Ottensmeier H, WarmuthMetz M, Bison B, Pfister S, Korshunov A, Sharma T, Jaeger N, Ryzhova M, Zheludkova O, Golanov A, Rushing EJ, Hasselblatt M, Koch A, Schüller U, von Deimling A, Sahm F, Sill M, Riemenschneider MJ, Dohmen H, Monoranu CM, Sommer C, Staszewski O, Mawrin C, Schittenhelm J, Brück W, Filipski K, Hartmann C, Meinhardt M, Pietschmann K, Haberler C, Slavc I, Gerber NU, Grotzer M, Benesch M, Schlegel PG, Deinlein F, von Bueren AO, Friedrich C, Juhnke BO, Obrecht D, Fleischhack G, Kwiecien R, Faldum A, Kortmann RD, Kool M, Rutkowski S (2020) Nonmetastatic medulloblastoma of early childhood: results from the prospective clinical trial HIT-2000 and an extended validation cohort. J Clin Oncol 38:2028-2040. https://doi.org/10.1200/JCO. 19.03057

16. Bhakta N, Liu Q, Ness KK, Baassiri M, Eissa H, Yeo F, Chemaitilly W, Ehrhardt MJ, Bass J, Bishop MW, Shelton K, Lu L, Huang S, Li Z, Caron E, Lanctot J, Howell C, Folse T, Joshi V, Green DM, Mulrooney DA, Armstrong GT, Krull KR, Brinkman TM, Khan RB, Srivastava DK, Hudson MM, Yasui Y, Robison LL (2017) The cumulative burden of surviving childhood cancer: an initial report from the St Jude Lifetime Cohort Study (SJLIFE). Lancet 390:2569-2582. https://doi.org/10.1016/S0140-6736(17) 31610-0

17. Gibson TM, Mostoufi-Moab S, Stratton KL, Leisenring WM, Barnea D, Chow EJ, Donaldson SS, Howell RM, Hudson MM, Mahajan A, Nathan PC, Ness KK, Sklar CA, Tonorezos ES, Weldon CB, Wells EM, Yasui Y, Armstrong GT, Robison LL, Oeffinger KC (2018) Temporal patterns in the risk of chronic health conditions in survivors of childhood cancer diagnosed 1970-99: a report from the Childhood Cancer Survivor Study cohort. Lancet Oncol 19:1590-1601. https://doi.org/10.1016/S1470-2045(18) 30537-0

18. Robinson GW, Rudneva VA, Buchhalter I, Billups CA, Waszak SM, Smith KS, Bowers DC, Bendel A, Fisher PG, Partap S, Crawford JR, Hassall T, Indelicato DJ, Boop F, Klimo P, Sabin ND, Patay Z, Merchant TE, Stewart CF, Orr BA, Korbel JO, Jones DTW, Sharma T, Lichter P, Kool M, Korshunov A, Pfister SM, Gilbertson RJ, Sanders RP, Onar-Thomas A, Ellison DW, Gajjar A, Northcott PA (2018) Risk-adapted therapy for young children with medulloblastoma (SJYC07): therapeutic and molecular outcomes from a multicentre, phase 2 trial. Lancet Oncol 19:768784. https://doi.org/10.1016/S1470-2045(18)30204-3

19. Mackay A, Burford A, Carvalho D, Izquierdo E, Fazal-Salom J, Taylor KR, Bjerke L, Clarke M, Vinci M, Nandhabalan M, Temelso S, Popov S, Molinari V, Raman P, Waanders AJ, Han HJ, Gupta S, Marshall L, Zacharoulis S, Vaidya S, Mandeville HC, Bridges LR, Martin AJ, Al-Sarraj S, Chandler C, Ng HK, Li X, Mu K, Trabelsi S, Brahim DH, Kisljakov AN, Konovalov DM, Moore AS, Carcaboso AM, Sunol M, de Torres C, Cruz O, Mora J, Shats LI, Stavale JN, Bidinotto LT, Reis RM, Entz-Werle N, Farrell M, Cryan J, Crimmins D, Caird J, Pears J, Monje M, Debily MA, Castel D, Grill J, Hawkins C, Nikbakht H, Jabado N, Baker SJ, Pfister SM, Jones DTW, Fouladi M, von Bueren AO, Baudis M, Resnick A, Jones C (2017) Integrated molecular meta-analysis of 1,000 pediatric high-grade and diffuse intrinsic pontine glioma. Cancer Cell 32:520-537.e525. https://doi.org/10. 1016/j.ccell.2017.08.017

20. Guerreiro Stucklin AS, Ryall S, Fukuoka K, Zapotocky M, Lassaletta A, Li C, Bridge T, Kim B, Arnoldo A, Kowalski PE, Zhong Y, Johnson M, Ramani AK, Siddaway R, Nobre LF, de Antonellis P, Dunham C, Cheng S, Boué DR, Finlay JL, Coven SL, de Prada I, Perez-Somarriba M, Faria CC, Grotzer MA, Rushing E, Sumerauer D, Zamecnik J, Krskova L, Garcia Ariza M, Cruz O, Morales La Madrid A, Solano P, Terashima K, Nakano Y, Ichimura K, Nagane M, Sakamoto H, Gil-da-Costa MJ, Silva R, Johnston DL, Michaud J, Wilson B, van Landeghem FKH, Oviedo A, McNeely PD, Crooks B, Fried I, Zhukova N, Hansford JR, Nageswararao A, Garzia L, Shago M, Brudno M, Irwin MS, Bartels U, Ramaswamy V, Bouffet E, Taylor MD, Tabori U, Hawkins C (2019) Alterations in ALK/ROS1/NTRK/MET drive a group of infantile hemispheric gliomas. Nat Commun 10:4343. https://doi.org/10. 1038/s41467-019-12187-5

21. Krishnatry R, Zhukova N, Guerreiro Stucklin AS, Pole JD, Mistry M, Fried I, Ramaswamy V, Bartels U, Huang A, Laperriere N, Dirks P, Nathan PC, Greenberg M, Malkin D, Hawkins C, Bandopadhayay P, Kieran MW, Manley PE, Bouffet E, Tabori U (2016) Clinical and treatment factors determining long-term outcomes for adult survivors of childhood low-grade glioma: a population-based study. Cancer 122:1261-1269. https://doi.org/ 10.1002/cncr.29907

22. Tran S, Lim PS, Bojaxhiu B, Teske C, Baust K, Zepter S, Kliebsch U, Timmermann B, Calaminus G, Weber DC (2020) Clinical outcomes and quality of life in children and adolescents with primary brain tumors treated with pencil beam scanning proton therapy. Pediatr Blood Cancer 67:e28465. https://doi.org/10. $1002 / \mathrm{pbc} .28465$

23. Desandes E, Guissou S, Chastagner P, Lacour B (2014) Incidence and survival of children with central nervous system primitive tumors in the French National Registry of Childhood Solid Tumors. Neuro Oncol 16:975-983. https://doi.org/10. 1093/neuonc/not309

24. Lannering B, Sandström PE, Holm S, Lundgren J, Pfeifer S, Samuelsson U, Strömberg B, Gustafsson G, (VCTB) SCCTWG (2009) Classification, incidence and survival analyses of children with CNS tumours diagnosed in Sweden 1984-2005. Acta Paediatr 98:1620-1627. https://doi.org/10.1111/j.1651-2227. 2009.01417.x

25. Pillai S, Metrie M, Dunham C, Sargent M, Hukin J, Steinbok P (2012) Intracranial tumors in infants: long-term functional outcome, survival, and its predictors. Childs Nerv Syst 28:547-555. https://doi.org/10.1007/s00381-012-1707-y

26. Renzi S, Michaeli O, Ramaswamy V, Huang A, Stephens D, Maguire B, Tabori U, Bouffet E, Bartels U (2020) Causes of death in pediatric neuro-oncology: the sickkids experience from 2000 to 2017. J Neurooncol 149:181-189. https://doi.org/10.1007/ s11060-020-03590-w

27. Qaddoumi I, Sultan I, Gajjar A (2009) Outcome and prognostic features in pediatric gliomas: a review of 6212 cases from the surveillance, epidemiology, and end results database. Cancer 115:5761-5770. https://doi.org/10.1002/cncr.24663

28. Qaddoumi I, Carey SS, Conklin H, Jenkins J, Sabin N, Boop F, Pai-Panandiker A, Baker J, Wright K, Broniscer A, Gajjar A (2011) Characterization, treatment, and outcome of intracranial neoplasms in the first 120 days of life. J Child Neurol 26:988-994. https://doi.org/10.1177/0883073811401398

29. Armstrong GT, Liu Q, Yasui Y, Huang S, Ness KK, Leisenring W, Hudson MM, Donaldson SS, King AA, Stovall M, Krull KR, Robison LL, Packer RJ (2009) Long-term outcomes among adult survivors of childhood central nervous system malignancies in the 
Childhood Cancer Survivor Study. J Natl Cancer Inst 101:946958. https://doi.org/10.1093/jnci/djp148

30. Packer RJ, Gurney JG, Punyko JA, Donaldson SS, Inskip PD, Stovall M, Yasui Y, Mertens AC, Sklar CA, Nicholson HS, Zeltzer LK, Neglia JP, Robison LL (2003) Long-term neurologic and neurosensory sequelae in adult survivors of a childhood brain tumor: childhood cancer survivor study. J Clin Oncol 21:3255-3261. https://doi.org/10.1200/JCO.2003.01.202

31. Whelan K, Stratton K, Kawashima T, Leisenring W, Hayashi S, Waterbor J, Blatt J, Sklar CA, Packer R, Mitby P, Robison LL, Mertens AC (2011) Auditory complications in childhood cancer survivors: a report from the childhood cancer survivor study. Pediatr Blood Cancer 57:126-134. https://doi.org/10.1002/pbc.23025

32. Brinkman TM, Bass JK, Li Z, Ness KK, Gajjar A, Pappo AS, Armstrong GT, Merchant TE, Srivastava DK, Robison LL, Hudson MM, Gurney JG (2015) Treatment-induced hearing loss and adult social outcomes in survivors of childhood CNS and nonCNS solid tumors: Results from the St. Jude Lifetime Cohort Study. Cancer 121:4053-4061. https://doi.org/10.1002/cncr.29604

33. Sklar CA, Constine LS (1995) Chronic neuroendocrinological sequelae of radiation therapy. Int J Radiat Oncol Biol Phys 31:1113-1121. https://doi.org/10.1016/0360-3016(94)00427-M

34. Crowne E, Gleeson H, Benghiat H, Sanghera P, Toogood A (2015) Effect of cancer treatment on hypothalamic-pituitary function. Lancet Diabetes Endocrinol 3:568-576. https://doi.org/10.1016/ S2213-8587(15)00008-X

35. van Iersel L, van Santen HM, Potter B, Li Z, Conklin HM, Zhang H, Chemaitilly W, Merchant TE (2020) Clinical impact of hypothalamic-pituitary disorders after conformal radiation therapy for pediatric low-grade glioma or ependymoma. Pediatr Blood Cancer 67:e28723. https://doi.org/10.1002/pbc.28723

36. Lebbink CA, Ringers TP, Schouten-van Meeteren AYN, van Iersel L, Clement SC, Boot AM, Claahsen-van der Grinten HL, Janssens GO, van Vuurden DG, Michiels EM, Han KS, van Trotsenburg ASP, Vandertop WP, Kremer LCM, van Santen HM (2021) Prevalence and risk factors of hypothalamic-pituitary dysfunction in infant and toddler childhood brain tumor survivors. Eur J Endocrinol. https://doi.org/10.1530/EJE-21-0137

37. Gurney JG, Kadan-Lottick NS, Packer RJ, Neglia JP, Sklar CA, Punyko JA, Stovall M, Yasui Y, Nicholson HS, Wolden S, McNeil DE, Mertens AC, Robison LL, Study CCS (2003) Endocrine and cardiovascular late effects among adult survivors of childhood brain tumors: childhood cancer survivor study. Cancer 97:663673. https://doi.org/10.1002/cncr.11095

38. Eaton BR, Goldberg S, Tarbell NJ, Lawell MP, Gallotto SL, Weyman EA, Kuhlthau KA, Ebb DH, MacDonald SM, Yock TI (2020) Long-term health related quality of life in pediatric brain tumor survivors treated with proton radiotherapy at $<4$ years of age. Neuro Oncol. https://doi.org/10.1093/neuonc/noaa042

39. Pang JW, Friedman DL, Whitton JA, Stovall M, Mertens AC, Robison LL, Weiss NS (2008) Employment status among adult survivors in the Childhood Cancer Survivor Study. Pediatr Blood Cancer 50:104-110. https://doi.org/10.1002/pbc.21226

40. Frobisher C, Lancashire ER, Jenkinson H, Winter DL, Kelly J, Reulen RC, Hawkins MM (2017) Employment status and occupational level of adult survivors of childhood cancer in Great Britain: the British childhood cancer survivor study. Int J Cancer 140:2678-2692. https://doi.org/10.1002/ijc.30696

41. Lancashire ER, Frobisher C, Reulen RC, Winter DL, Glaser A, Hawkins MM (2010) Educational attainment among adult survivors of childhood cancer in Great Britain: a population-based cohort study. J Natl Cancer Inst 102:254-270. https://doi.org/10. 1093/jnci/djp498

42. Mitby PA, Robison LL, Whitton JA, Zevon MA, Gibbs IC, Tersak JM, Meadows AT, Stovall M, Zeltzer LK, Mertens AC, Committee CCSSS (2003) Utilization of special education services and educational attainment among long-term survivors of childhood cancer: a report from the childhood cancer survivor study. Cancer 97:1115-1126. https://doi.org/10.1002/cncr.11117

43. Louis DN, Perry A, Wesseling P, Brat DJ, Cree IA, FigarellaBranger D, Hawkins C, Ng HK, Pfister SM, Reifenberger G, Soffietti R, von Deimling A, Ellison DW (2021) The 2021 WHO classification of tumors of the central nervous system: a summary. Neuro Oncol 23:1231-1251. https://doi.org/10.1093/neuonc/noab106

Publisher's Note Springer Nature remains neutral with regard to jurisdictional claims in published maps and institutional affiliations. 